Authors: R Botha and J Visser

FORCEFUL ARRESTS: AN OVERVIEW OF SECTION 49 OF THE CRIMINAL PROCEDURE ACT 51 OF 1977 AND ITS RECENT AMENDMENTS

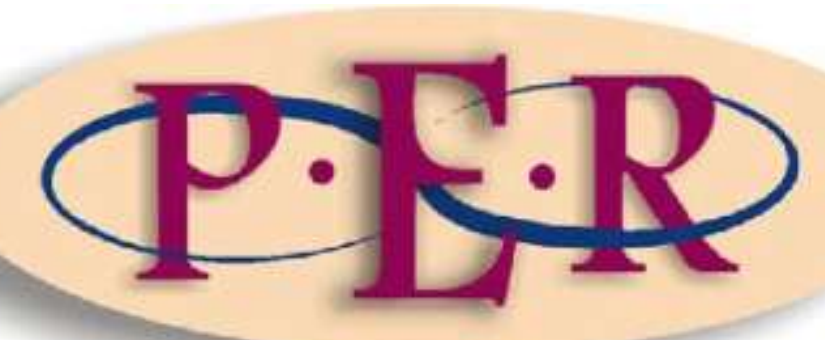

2012 VOLUME 15 No 2 


\section{FORCEFUL ARRESTS: AN OVERVIEW OF SECTION 49 OF THE CRIMINAL PROCEDURE ACT 51 OF 1977 AND ITS RECENT AMENDMENTS}

R Botha*

J Visser**

\section{Introduction}

Members of the police in South Africa are burdened with a Constitutional duty ${ }^{1}$ to prevent, investigate and combat crime, a duty to maintain law and public order, and to ensure the protection and security of all South Africans. ${ }^{2}$ This is no easy task, as South Africa boasts with some of the gravest crime statistics in the world. ${ }^{3}$

Police power to arrest is vital in the implementation of this duty to combat crime, but is also a concept demanding careful balancing of the suspect's rights to dignity, ${ }^{4}$ life,${ }^{5}$ and freedom and security of person, ${ }^{6}$ with society's entitlement to the same rights. The use of force while effecting arrests is legitimate in most systems of law. ${ }^{7}$ However, what normally gives rise to dispute, is the degree of force to be permitted. ${ }^{8}$

Section 49 of the South African Criminal Procedure Act 51 of 1977, provides police officers with legal justification to use force in carrying out arrests, and includes the rules governing the degree of force to be used, as well as the circumstances in which such force may be employed. Where a police officer's forceful conduct

Rinda Botha LLB, LLM, LLD (UFS), Senior lecturer in the Department of Criminal and Medical Law, University of the Free State, Bloemfontein, South Africa, bothar@ufs.ac.za.

** Advocate Jo-Mari Visser BSc, BMedSc Honours (UFS), MSc (UP), LLB (UFS), Lecturer in the Department of Procedural Law and Law of Evidence, University of the Free State, Bloemfontein, South Africa, visserjm@ufs.ac.za.

1 S 205(3) of the Constitution of the Republic of South Africa of 1996 (hereafter the Constitution).

2 Ex Parte Minister of Safety and Security and Others: In re S v Walters and Another [2002] 4 SA 613 (CC) 640: par 48.

3 Harrendorf et al. (Eds) International statistics on crime and justice 11.

While the world average homicide rate in 2008 was 7,6 murders per 100000 people, the South African average for the same year was 36,5 murders per 100000 people.

S 10 of the Constitution of the Republic of South Africa of 1996.

$\mathrm{S} 11$ of the Constitution.

S 12 of the Constitution.

Burchell South African Criminal Law \& Procedure 198.

Burchell South African Criminal Law \& Procedure 198. 
extends beyond the ambit of these legislative provisions, that officer may be subject to criminal liability. ${ }^{9}$

The authority of police to employ force, even deadly force, in effecting arrests has been subject to intense judicial, ${ }^{10}$ as well as media scrutiny over the past few years. In 2003, police powers to use deadly force was considered and subsequently limited by a Constitutional Court decision in Ex Parte Minister of Safety and Security: In re S $v$ Walters. ${ }^{11}$ Section 49(2) of the Criminal Procedure Act 51 of 1977 was deemed unconstitutional and declared invalid. ${ }^{12}$

Subsequent to the constitutional invalidation of section 49(2), the legislature promulgated a 2003 redefined section 49. The amendments to section 49 were met with some controversy. Some authors ${ }^{13}$ viewed this decision as a legislative guarantee of a suspect's right to flee, while others ${ }^{14}$ stated that the 2003 redefined section 49 required arrestors to make split-second decisions in daunting circumstances, ${ }^{15}$ prompting one to reason that section 49 only sanctioned use of force during arrests in situations of private defence. This concern was shared by the Minister of Safety and Security at the time the 2003 redefined section 49 was promulgated. $^{16}$

In 2009, after the release of daunting statistics on the amount of police officers killed in the line of duty, ${ }^{17}$ senior government officials made public declarations that seemed to promote the idea of using deadly force in combating crime. ${ }^{18}$ This was

Burchell South African Criminal Law \& Procedure 197.

Du Toit et al. Commentary on the Criminal Procedure Act 5-25.

Ex Parte Minister of Safety and Security: In re S v Walters [2002] 4 SA 613 (CC).

12 Ex Parte Minister of Safety and Security: In re S v Walters [2002] 4 SA 613 (CC); Van der Walt T 2007 Tydskrif vir die Suid-Afrikaanse Reg 100.

13 Snyman Criminal Law 135.

14 Van der Walt 2007 Tydskrif vir die Suid-Afrikaanse Reg 105.

15 Fear of criminal prosecution when injuring of fatally wounding a person in an attempt to arrest him, might rob police officers of the fervour to perform this important policing task - Du Toit et al. Commentary on the Criminal Procedure Act 5-25.

16 Van der Walt 2011 Potchefstroom Electronic Journal 140.

17 During the 2008/2009 financial year of the SAPS, 109 officers were reportedly killed in the line of duty, while 107 perished during the 2009/2010 year - South African Police Service 2008/2009 Annual Report 20 and 2009/2010 Annual Report 18.

18 Open Society Foundation for South Africa Report on the OSF-SA roundtable discussion on the human rights and practical implications of the proposed amendment to section 49 of the Criminal Procedure Act 2010:1; Smith 2009 www.guardian.co.uk/world/2009/sep/16/south-africa-policeworld-cup. 
followed by prominent cases of abuse of the power to use lethal force. ${ }^{19}$ In fact, it has been reported that during 2008/2009 and 2009/2010, at least 1092 people lost their lives as a result of the use of force by the police, the highest number since the late 1990's. ${ }^{20}$ This seems peculiar, as there were no legislative or policy amendments regarding the use of force by police during this time.

Bruce $^{21}$ argues that, in light of the fact that the very objective of a police force is to protect human life, misuse of force by police may give rise to public instability and essentially to decreased safety of police officers in carrying out their duties. Reports of misuse of force can perhaps then easily explain the spate of murdered police officers in recent years.

In light of recent controversies regarding use of force and police killings, as well as severe concerns about the difficulty in the proper interpretation of the 2003 redefined section $49,{ }^{22}$ an amendment to section 49 has been formulated in the shape of the Criminal Procedure Amendment Bill of $2010,{ }^{23}$ which, at the time of publication of this study, was approved by the National Assembly without assent, and is due for concurrence by the National Council of Provinces. ${ }^{24}$

This article endeavours to investigate the desirability of the planned legislative reform. A comparative study will also be conducted to assess whether the South African legal position pertaining to use of force is in line with that of foreign jurisdictions and to facilitate the formulation of possible recommendations for favourable regulation of forceful arrests.

Understanding current legislative provisions and creating clear and efficient new laws to empower police officials to effect forceful arrests are vital in establishing legal

\footnotetext{
19 Bruce 2011 South African Crime Quarterly 3.

20 Bruce 2011 South African Crime Quarterly 3; Van der Walt 2011 Potchefstroom Electronic Law Journal 145 footnote 45.

21 Bruce 2011 South African Crime Quarterly 4.

22 Snyman Criminal Law 137.

23 GN 949 in GG 33619 of 7 October 2010; Open Society Foundation for South Africa Report on the OSF-SA roundtable discussion on the human rights and practical implications of the proposed amendment to section 49 of the Criminal Procedure Act 2010:2.

24 SabinetLaw 2012 www.sabinetlaw.co.za/defence-and-security/articles/national-assemblypasses-saps-bill.
} 
certainty, as well as providing the police with much-needed guidance in performing their sometimes very dangerous constitutional duty.

\section{Historical development}

Section 49 and its predecessors ${ }^{25}$ have been contained in South Africa's law books for more than 165 years. ${ }^{26}$ It is one of the most amended sections in the South African criminal procedure, having been amended four times, with a fifth amendment currently underway. ${ }^{27}$ Due to the nature and extent thereof it has always been subject to criticism, even before the birth of the Constitution. ${ }^{28}$

The two most significant decisions influencing the reform of the old section 49 , are Govender $v$ Minister of Safety and Security ${ }^{29}$ and Ex parte Minister of Safety and Security: in re $S v$ Walters. ${ }^{30}$ At the time these cases were decided, section 49 of the Criminal Procedure Act 51 of $1977^{31}$ read as follows:

49. Use of force in effecting arrest

(1) If any person authorised under this Act to arrest or to assist in arresting another, attempts to arrest such person and such person-

(a) resists the attempt and cannot be arrested without the use of force; or

(b) flees when it is clear that an attempt to arrest him is being made, or resists such attempt and flees;

the person so authorised may, in order to effect the arrest, use such force as may in the circumstances be reasonably necessary to overcome the resistance or to prevent the person concerned from fleeing.

(2) Where the person concerned is to be arrested for an offence referred to in Schedule 1 or is to be arrested on the ground that

\footnotetext{
25 S 1 of Ordinance 2 of 1837 (C); s 41 of the Criminal Procedure Ordinance 1 of 1903 (T); s 44 of the Criminal Procedure Act 31 of 1917 and s 37 of the Criminal Procedure Act 56 of 1955. Van der Walt T 2007 Tydskrif vir die Suid-Afrikaanse Reg 96. See also in this regard Van der Walt T 2011 Potchefstroom Electronic Law Journal 138.

27 Le Roux-Kemp and Horne 2011 SACJ 266.

28 Ex Parte Minister of Safety and Security and Others: In re S v Walters and Another [2002] 4 SA 613 (CC) 629. See also Van der Walt 2007 Tydskrif vir die Suid-Afrikaanse Reg 97. [2001] 4 SA 273 (SCA). [2002] 4 SA 613 (CC).

Some refer to this piece of legislation as the section dealing with the use of lethal force in the preconstitutional era - Le Roux-Kemp and Horne 2011 SACJ 271.
} 
he is reasonably suspected of having committed such an offence, and the person authorised under this Act to arrest or to assist in arresting him cannot arrest him or prevent him from fleeing by other means than by killing him, the killing shall be deemed justifiable.

From the above it is clear that section 49(1) provided the framework for the use of force only, while section 49(2) set the framework for circumstances under which the use of deadly force would be justified. ${ }^{32}$ Govender $v$ Minister of Safety and Security ${ }^{33}$ contributed to the development of section 49(1), while Ex Parte Minister of Safety and Security: in re $S v$ Walters $^{34}$ lead to the declaration of unconstitutionality of section $49(2){ }^{35}$

A brief discussion of the abovementioned cases and development of section 49(1) and $49(2)$ respectively, will now follow. 


\subsection{Govender v Minister of Safety and Security [2001] 4 SA 273 (SCA)}

In an appeal following the High Court's ruling that a police officer's conduct, namely shooting at a 17 year old boy during an attempted car theft, was not unlawful, the Supreme Court of Appeal had to investigate the proper interpretation of the old section 49(1) of the Criminal Procedure Act. ${ }^{36}$

On behalf of the appellant it was argued that section 49(1) violated the following rights contained in the Interim Constitution of the Republic of South Africa 200 of 1993: the right to life, ${ }^{37}$ the right to physical integrity, ${ }^{38}$ the right to protection of dignity, ${ }^{39}$ the right to be presumed innocent until convicted by a court of $\operatorname{law}^{40}$ and the right to equality before the law and to equal protection from the law. ${ }^{41}$ The question arose whether these limitations passed the test of being "reasonable" and "justifiable" as set out in section 33(1) of the Interim Constitution. ${ }^{42}$

The court, in answering the above, was of the opinion that it depended on the proper interpretation of section $49(1) .{ }^{43}$ It is clearly the purpose of section 49 to protect the safety and security of all persons. This, however, must be brought into balance with the constitutional rights also enjoyed by the fleeing suspect. ${ }^{44}$

The Court explained that the threshold requirement for the use of force, as previously interpreted, was extremely low. ${ }^{45}$ It was previously raised in the case Matlou $v$ Makhubedu ${ }^{46}$ where the Court of Appeal held that a proportionality test must be included in the interpretation of the words reasonably necessary as found in the then section 49(1). More specifically, in the Matlou-case, the court required

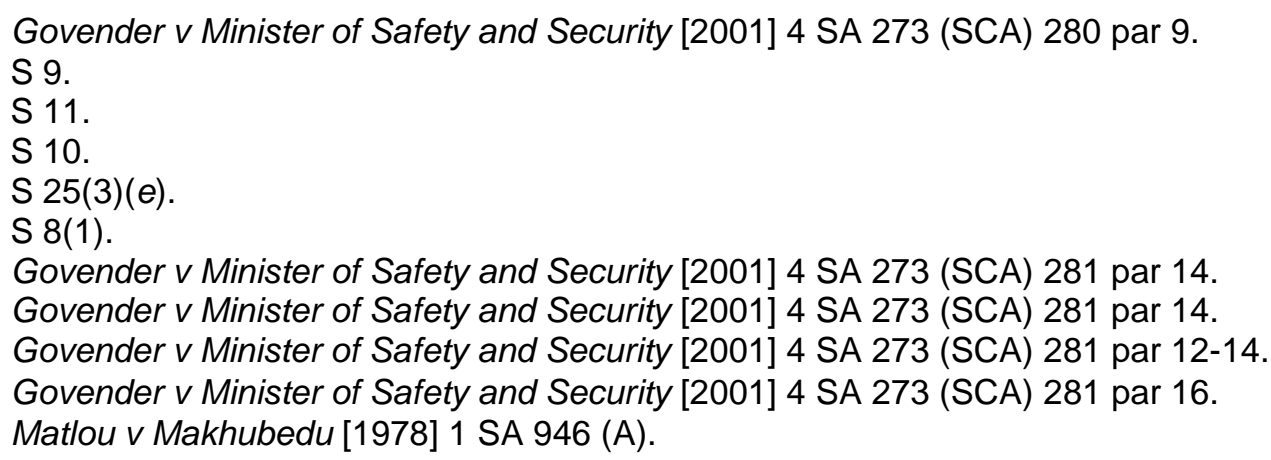


proportionality between the degree of force used by the arresting officer and the seriousness of the crime committed by the arrestee. ${ }^{47}$

However, the appellant in the Govender-case argued that even the "raised" threshold requirement as laid down in the Matlou-decision was too low to comply with the constitutional values of reasonableness and justifiability. ${ }^{48}$

Therefore, and with due consideration to the American case, Tennessee $v$ Garner, ${ }^{49}$ the court in the Govender-case expanded the proportionality requirement further and held that an additional factor to be considered was whether the suspect posed an immediate threat or danger of serious physical harm to the arresting officer, others and society as a whole. ${ }^{50}$

The court stated that:

The words "use such force as may in the circumstances be reasonably necessary to prevent the person concerned from fleeing" in section 49(1)(b) of the Act must therefore generally speaking (there may be exceptions) be interpreted so as to exclude the use of a firearm or similar weapon unless the person authorised to arrest, or assist in arresting, a fleeing suspect has reasonable grounds for believing:

1 that the suspect poses an immediate threat of serious bodily harm to him or her, or a threat of harm to members of the public; or

2 that the suspect has committed a crime involving the infliction or threatened infliction of serious bodily harm. ${ }^{51}$

$47 \quad$ As cited in Govender v Minister of Safety and Security 2001 (4) SA 281-282 (SCA) 282 par 16. Also see Du Toit et al. Commentary on the Criminal Procedure Act 5-27; Neethling and Potgieter 2004 Tydskrif van die Suid-Afrikaanse Reg 604.

$48 \quad$ Govender v Minister of Safety and Security [2001] 4 SA 273 (SCA) 282 par 17.

49 Tennessee v Garner 471 U.S. 1, 85 L.Ed.2d 1, 105 S.Ct. 1694 (1985). In this Supreme Court case decided in 1985, the court delineated criteria for the use of force when arresting a fleeing suspect in the United States of America. Several principles were formulated to replace the previously used 'any means necessary' requirement that allowed for a wide scope of opportunity to use excessive force in effecting arrests of fleeing suspects or those resisting arrest in America. See the discussion on comparative law below.

50 Govender v Minister of Safety and Security [2001] 4 SA 273 (SCA) 282-283 par 17-22. Also see Burchell South African Criminal Law and Procedure 201.

51 Govender v Minister of Safety and Security [2001] 4 SA 273 (SCA) 284 par 24. Also see Le Roux-Kemp and Horne 2011 SACJ 274. 
Interpreting section 49(1) as explained above, the court came to the conclusion that the conduct of the police officer, shooting at an unarmed 17 years old who posed no threat or danger to the arrestor or society, was unlawful. ${ }^{52}$

\subsection{Ex Parte Minister of Safety and Security: in re $S v$ Walters and Another [2002] 4 SA 613 (CC)}

Contrary to the Govender-case, the court in Ex parte: Minister of Safety and Security: in re $S v$ Walters ${ }^{53}$ had to decide on the constitutionality of section 49(2) of the Criminal Procedure Act 51 of $1977 . .^{54}$

The criminal prosecution in this case arose as a result of a shooting incident following a break-in at the bakery of Accused 1 and 2 (father and son), causing the death of the burglar. The accused persons were charged with murder and raised section $49(2)$ as ground of justification. ${ }^{55}$ The trial judge found the section to be inconsistent with the Constitution of the Republic of South Africa of 1996, specifically with regards to the suspect's constitutional rights to life, human dignity and bodily integrity. The court held that this limitation of the constitutional rights could not be justified in terms of section 36 of the Constitution. ${ }^{56}$ A declaration of invalidity of section 49(2) was compiled and, in terms of section 172(2)(a) of the Constitution, referred to the Constitutional Court for confirmation. ${ }^{57}$

The Constitutional Court, in deciding the matter, stated that the test accepted in the Govender-case as prerequisite to the use of force (section 49(1)), should at the very least also be the prerequisite for the use of deadly violence (section 49(2)). ${ }^{58}$ In addition to this, the court held that insufficient proportionality existed between the

Govender v Minister of Safety and Security [2001] 4 SA 273 (SCA) 283-284 par 21-24.

Ex parte: Minister of Safety and Security: in re S v Walters [2002] 4 SA 613 (CC).

Van der Walt 2007 Tydskrif vir die Suid-Afrikaanse Reg 98. See also discussion in Du Toit Commentaries on the Criminal Procedure Act 5-33.

55 Ex Parte Minister of Safety and Security and Others: In re $S v$ Walters and Another [2002] 4 SA 613 (CC) 623.

56 Ex Parte Minister of Safety and Security and Others: In re $S v$ Walters and Another [2002] 4 SA 613 (CC) 623.

57 Ex Parte Minister of Safety and Security and Others: In re $S v$ Walters and Another [2002] 4 SA 613 (CC) 623.

58 Ex Parte Minister of Safety and Security and Others: In re $S v$ Walters and Another [2002] 4 SA 613 (CC) 615. Also see Le Roux-Kemp and Horne 2011 SACJ 275. 
employment of deadly force in effecting arrests and the broad list of offences contained in Schedule 1 of the Criminal Procedure Act. ${ }^{59}$ The court held:

The Schedule lists a widely divergent rag-bag of some 20 offences, ranging from really serious crimes with an element of violence, such as treason, public violence, murder, rape and robbery at one end of the spectrum to, at the other end, relatively petty offences, such as picketpocketing or grabbing a mealie from a fruit-stall. What is more, the Schedule includes offences that do not constitute any kind of physical threat, let alone violence. ${ }^{60}$

It was therefore emphasised that the list was "simply too wide and inappropriately focused to permit a constitutionally defensible line to be drawn for the permissible use of deadly force." ${ }^{61}$ Du Toit et al. ${ }^{62}$ suggests the inclusion of Schedule 1 fails to fulfill the legislature's intention to distinguish between serious and less serious offences and does therefore not succeed in serving as test for proportionality.

59 Ex Parte Minister of Safety and Security and Others: In re $S v$ Walters and Another [2002] 4 SA 613 (CC) 614.

Schedule 1 includes the following crimes:

Treason.

Sedition.

Public violence.

Murder.

Culpable homicide.

Rape.

Indecent assault (at present known as sexual assault in terms of section 5 of the Sexual Offences Amendment Act).

Bestiality.

Robbery.

Kidnapping.

Childstealing.

Assault, when a dangerous wound is inflicted.

Arson.

Malicious injury to property.

Breaking or entering any premises, with intent to commit an offence.

Theft.

Receiving of stolen property knowing it to have been stolen.

Fraud.

Forgery and uttering.

Any offence, except the offence of escaping from lawful custody in circumstances other than the circumstances referred to immediately hereunder, the punishment wherefore may be a period of imprisonment exceeding six months without the option of a fine.

Escaping from lawful custody, where the person concerned is in such custody in respect of any offence referred to in this Schedule or is in such custody in respect of the offence of escaping from lawful custody.

Any conspiracy, incitement or attempt to commit any offence referred to in this Schedule. Ex Parte Minister of Safety and Security and Others: In re S v Walters and Another [2002] 4 SA 613 (CC) 615-616.

61 Ex Parte Minister of Safety and Security and Others: In re S v Walters and Another [2002] 4 SA 613 (CC) 616.

62 Du Toit et al.Commentary on the Criminal Procedure Act 5-27 and 5-33.. 
Burchell ${ }^{63}$ confirms this sentiment and notes the absence of any reference to Schedule 1 in the 2003 redefined section 49.

Section 49(2) of the Criminal Procedure Act was accordingly deemed unconstitutional as it unjustifiably violated the rights to dignity, life and security of person. ${ }^{64}$ However, the court was of the opinion that to simply remove section $49(2)$ as shield against criminal prosecution would be against the principle of legality that does not only form part of our criminal law, but is also supported by section $35(3)(I)$ of the Constitution. ${ }^{65}$

The great value of this case lies in the list of given factors to be considered by police officials when performing arrests: ${ }^{66}$

a) The purpose of arrest is to bring before court for trial persons suspected of having committed offences;

b) Arrest is not the only means of achieving this purpose, nor always the best;

C) Arrest may never be used to punish a suspect;

d) Where arrest is called for, force may be used only where it is necessary in order to carry out the arrest;

e) Where force is necessary, only the least degree of force reasonably necessary to carry out the arrest may be used;

f) In deciding what degree of force is both reasonable and necessary, all the circumstances must be taken into account, including the threat of violence the suspect poses to the arrestor or others, and the nature and circumstances of the offence the suspect is suspected of having committed, the force being proportional in all these circumstances;

g) Shooting a suspect solely in order to carry out an arrest is permitted in very limited circumstances only;

Burchell South African Criminal Law and Procedure 207.

Burchell South African Criminal Law and Procedure 202.

Ex Parte Minister of Safety and Security and Others: In re $S v$ Walters and Another [2002] 4 SA 613 (CC) 616.

66 Ex Parte Minister of Safety and Security and Others: In re $S v$ Walters and Another [2002] 4 SA 613 (CC) 616. Also see Du Toit et al. Commentary on the Criminal Procedure Act 5-28 - 5-30; Burchell South African Criminal Law and Procedure 202-203. 
h) Ordinarily, such shooting is not permitted unless the suspect poses a threat of violence to the arrestor or others or is suspected on reasonable grounds of having committed a crime involving the infliction or threatened infliction of serious bodily harm and there are no other reasonable means of carrying out the arrest, whether at that time or later;

i) These limitations in no way detract the rights of an arrestor attempting to carry out an arrest to kill a suspect in self-defence or in defence of any other person.

The final order given by the court in this matter was that the interpretation of section $49(1)(b)$ in the Govender-decision ${ }^{67}$ was sound and that section 49(2) of the Criminal Procedure Act 51 of 1977 was indeed inconsistent with the Constitution and invalid. The declaration of unconstitutionality of section $49(2)$ was prospective only. ${ }^{68}$

\section{The 2003 redefined section 49}

Following its constitutional considerations, section 49 was amended by section 7 of the Judicial Matters Second Amendment Act 122 of 1998. This Act was controversial as it had already been formulated in 1998 but, due to severe criticism by the then Minister of Safety and Security, was not yet implemented. ${ }^{69}$ It only came into force in 2003, after a delay of five years. ${ }^{70}$ The 2003 redefined section 49 as amended by the Judicial Matters Second Amendment Act, reads as follows:

(1) For the purposes of this section-

(a) "arrestor" means any person authorised under this Act to arrest or to assist in arresting a suspect; and

(b) "suspect" means any person in respect of whom an arrestor has or had a reasonable suspicion that such person is committing or has committed an offence.

(2) If any arrestor attempts to arrest a suspect and the suspect resists the attempt, or flees, or resists the attempt and flees, when it is clear

\footnotetext{
67 Ex Parte Minister of Safety and Security and Others: In re S v Walters and Another [2002] 4 SA 613 (CC) 635.

68 Ex Parte Minister of Safety and Security and Others: In re S v Walters and Another [2002] 4 SA 613 (CC) 652-653.

69 Van der Walt 2007 Tydskrif vir die Suid-Afrikaanse Reg (1):103-104.

70 Burchell South African Criminal Law \& Procedure 201. Also see Le Roux-Kemp and Horne 2011 SACJ 273; Van der Walt 2011 Potchefstroom Electronic Journal 139.
} 
that an attempt to arrest him or her is being made, and the suspect cannot be arrested without the use of force, the arrestor may, in order to effect the arrest, use such force as may be reasonably necessary and proportional in the circumstances to overcome resistance or to prevent the suspect from fleeing: Provided that the arrestor is justified in terms of this section in using deadly force that is intended or is likely to cause death or grievous bodily harm to a suspect, only if he or she believes on reasonable grounds-

(a) that the force is immediately necessary for the purpose of protecting the arrestor, any person lawfully assisting the arrestor or any other person from imminent or future death or grievous bodily harm;

(b) that there is a substantial risk that the suspect will cause imminent or future death or grievous bodily harm if the arrest is delayed; or

(c) that the offence for which the arrest is sought is in progress and is of a forcible and serious nature and involves the use of life threatening violence or a strong likelihood that it will cause grievous bodily harm. ${ }^{71}$

\subsection{The effect and interpretation of the 2003 redefined section 49}

From the above it is clear that the 2003 redefined section 49(1) no longer provides the framework for the use of force, but only defines the terms 'arrestor' and 'suspect'. Section 49(2) describes the circumstances in which force, as well as deadly force, may be employed. While the first part of section 49(2) addresses the use of force only, the concluding part sets the boundaries for the use of deadly force.

What is also clear from the wording of the 2003 redefined section 49(2) is that the description of the circumstances in which the use of force would be allowed (what used to be section 49(1)), remained almost unchanged except for the inclusion of the 'proportional' requirement. ${ }^{72}$ Force should no longer only be 'reasonably necessary', but also 'proportional'. This test is now known as the proportionality test, ${ }^{73}$ and applies to both the use of force and the use of deadly force. ${ }^{74}$

\footnotetext{
Snyman Criminal law 130.

Sibanda and Keebine-Sibanda 2003 Crime Research in South Africa s.p.

Le Roux-Kemp and Horne 2011 SACJ 277.

Burchell South African Criminal Law and Procedure 203.
} 
The requirement that the use of force must be 'reasonably necessary', is generally interpreted as meaning that whatever force used must have been the only viable alternative to guarantee a successful arrest. If any other means of carrying out the arrest was available to the arrestor, those means should have been exhausted. In addition to this, the arrestor must, before discharging a firearm at a suspect, issue a verbal warning followed by the discharge of a warning shot. In the event that this does not have the desired effect, the arrestor should direct a shot at the lower extremities of the suspect, rather than the rest of his body. ${ }^{75}$

With reference to the 'proportionality' requirement, it is clear from the Matlou- and Govender-interpretations that the force should not only be proportional to the seriousness of the crime the suspect is thought to have committed, but also to the threat or danger the suspect poses to the arrestor, bystanders and society as a whole. This view was confirmed in the recent decision of April v Minister of Safety and Security. ${ }^{76}$

On the other hand, the second part of the 2003 redefined section 49(2) replaces the entire previous section 49(2) that was declared unconstitutional in the Walters-case and proves to be even stricter than suggested by the court in the Walters-decision. It now allows the use of deadly violence in the following circumstances:

Provided that the arrestor is justified in terms of this section in using deadly force that is intended or is likely to cause death or grievous bodily harm to a suspect, only if he or she believes on reasonable grounds-

(a) that the force is immediately necessary for the purpose of protecting the arrestor, any person lawfully assisting the arrestor or any other person from imminent or death or grievous bodily harm;

(b) that there is a substantial risk that the suspect will cause imminent or future death or grievous bodily harm if the arrest is delayed; or

(c) that the offence for which the arrest is sought is in progress and is of a forcible and nature and involves the use of life threatening violence or a strong likelihood it will cause grievous bodily harm. ${ }^{77}$ 
Neethling and Potgieter ${ }^{78}$ summarise the second part of the 2003 redefined section 49 as containing the following requirements:

(i) The arrestor must suspect on reasonable grounds;

(ii) That deadly force is immediately necessary;

(iii) To protect any person's life or body;

(iv) Against action that is immediately threatening or will happen in future.

According to the previous section 49(2), the arrestor was entitled to kill or seriously injure the suspect in an attempt to prevent him from fleeing, where the suspect has committed a serious offence (Schedule 1 offence) like murder, even where the conduct of the suspect when apprehended by the arrestor was not immediately threatening to the arrestor, bystanders or society as a whole, and even if there was no danger that the suspect would kill or seriously injure someone in the future. ${ }^{79}$ However, in terms of the 2003 redefined section 49(2), this is no longer possible. ${ }^{80}$ Burchell ${ }^{81}$ applauds the removal of the reference to Schedule 1 listed offences and the emphasis that the 2003 redefined section 49 places on offences involving serious violence.

Keebine-Sibanda and Sibanda ${ }^{82}$ note that, in addition to the 'reasonably necessary' and 'proportionality' requirements, the wording of the 2003 redefined section 49(2) also creates stricter conditions for the use of force by including phrases such as 'immediately necessary', 'substantial risk', 'forcible and serious nature' and 'strong likelihood'.

Snyman, ${ }^{83}$ however, opines against the wording of the second part of the 2003 redefined section 49(2), in that it is at best, careless. He suggests that the content of section $49(2)(b)$ does not really differ in any way from what is already captured in section $49(2)(a) .{ }^{84}$ This view is supported by Burchell ${ }^{85}$ as well as Neethling and Potgieter. ${ }^{86}$

\footnotetext{
Neethling and Potgieter 2004 Tydskrif vir die Suid-Afrikaanse Reg 605.

Snyman Criminal Law 134.

Le Roux-Kemp and Horne 2011 SACJ 278.

Burchell South African Criminal Law and Procedure 207.

Keebine-Sibanda and Sibanda 2003 Crime Research in South Africa s.p.

Snyman Criminal Law 132.

Snyman Criminal Law 132-133.
} 
The question also arose as to whether the 2003 redefined section 49(2), as possible ground of justification, does not simply boil down to common law private defence? Burchell, ${ }^{87}$ as well as Snyman, ${ }^{88}$ propose that it does not. This opinion is supported, as the 2003 redefined section 49(2) refers to 'future' threats of death or bodily harm. One can only be successful with a private defence if the threat posed is imminent or immediate, while in the case of the 2003 redefined section 49(2), one can succeed where one protects oneself or another from imminent or future death or grievous bodily harm.

Although this legislation provides for the protection of people against future harm, a great disadvantage to such a defence lies in the uncertainty as to what is meant by 'future danger'. ${ }^{89}$ Should a court interpret this concept narrowly, a section 49 defence would surely not succeed.

Burchell $^{90}$ raises concern about the introduction of the "future death" concept, arguing that to allow the use of deadly force where it is determined that a suspect might pose a threat in future, will only "serve to encourage a cycle of violence".

To shed some light on this ambiguity, the South African Police Service adopted a policy decision regarding the 'future death' concept. ${ }^{91} \mathrm{~A}$ threat of future death or grievous bodily harm would exist where a suspect was reasonably thought to be a serial murderer or rapist, although proof of past robberies would not qualify a suspect as being a serial robber and therefore would be excluded from posing a future threat. This, however, is unacceptable to the police and has been shown to lead to great confusion amongst police officers. ${ }^{92}$

\footnotetext{
Burchell South African Criminal Law and Procedure 204.

Neethling and Potgieter 2004 Tydskrif vir die Suid-Afrikaanse Reg 605.

Burchell South African Criminal Law and Procedure 205.

Snyman Criminal Law 134.

Bruce "Shoot to kill: The use of deadly force by police" 8.

Burchell South African Criminal Law and Procedure 205.

Geldenhuys "Shoot to kill: The use of deadly force by police" 10 . The wording, 'future death', was removed from the recently amended section 49 , but it is submitted that the concept thereof is still implied with the removal of the word "immediate" before threat. See below. Geldenhuys "Shoot to kill: The use of deadly force by police" 10 .
}

92 
Neethling and Potgieter ${ }^{93}$ suggest that a future threat to death or serious harm exists where "the suspect has committed a crime involving the infliction or threatened infliction of serious bodily harm."

Snyman ${ }^{94}$ provides the following example:

If, for example, the police have reliable information that $Y$ has conspired with others to kill someone in three days' time, or if they know that $Y$ is a serial killer or rapist that will repeat her vile acts in future, they may kill or grievously harm $Y$ during arrest, even though Y's actions during the arrest do not constitute an immediate threat to anyone at the scene.

Bruce $^{95}$ proposes that, to ascertain legal certainty on the matter of 'future' threats, legislation must be properly worded to eliminate any vagueness. He suggests the following wording:

Police officers may use deadly force to stop a fleeing suspect only if they have reasonable grounds to believe that the suspect (1) has committed an offence involving the actual or threatened infliction of serious physical injury or death, and (2) is likely to endanger human life or cause serious injury to another unless apprehended without delay. ${ }^{96}$

In conclusion, despite the arguable careless wording at times, it is submitted that the legislature, in its drafting of the 2003 redefined section 49(2), succeeded in at least complying with the minimum requirements as laid down in the Govender- and Walters-decisions. The 2003 redefined section 49(2) is in fact even stricter than suggested by the court in the Walters-decision and at the same time, stretches beyond what is known as common law private defence.

In the absence of clearly defined provisions or identifying criteria for what constitutes future threats, ${ }^{97}$ the policing community is expected to perform their arresting tasks

\footnotetext{
Neethling and Potgieter 2004 Tydskrif vir die Suid-Afrikaanse Reg 605.

Snyman Criminal Law 134.

Bruce "Shoot to kill: The use of deadly force by police" 9.

Bruce "Shoot to kill: The use of deadly force by police" 9 .

Also referred to as the "future danger" provision and comprehensively described in Van der Walt 2011 Potchefstroom Electronic Law Journal 141-143.
} 
without clear guidance on how to evaluate and recognise such threats. ${ }^{98}$ Clarifying this concept is therefore vital to prevent misuse and to provide legal certainty.

\section{$4 \quad$ Recent amendments to section 49}

In an apparent effort to clarify the legal position on the use of force in arresting suspects, government formulated legislation to amend the 2003 redefined section 49 of the Criminal Procedure Act 51 of 1977. Denying that its objective was to widen the circumstances under which police officers may use force to arrest suspects, government justified the formulation of amendment legislation by stating that the 2003 redefined section 49 exhibits ambiguities that detrimentally affect the police's ability to perform their tasks effectively, ${ }^{99}$ and that a need exists to align the provisions of section 49 with the constitutional court judgment in the Walters-case. The proposed amendment of the 2003 redefined section 49 was drafted and is set out as follows in the Criminal Procedure Amendment Bill: ${ }^{100}$

49. (1) For the purposes of this section-

(a) 'arrestor' means any person authorised under this Act to arrest or to assist in arresting a suspect; [and]

(b) 'suspect' means any person in respect of whom an arrestor has [or had] a reasonable suspicion that such person is committing or has committed an offence; and

(c) 'deadly force' means force that is likely to cause serious bodily harm or death and includes, but is not limited to, shooting at a suspect with a firearm.

(2) If any arrestor attempts to arrest a suspect and the suspect resists the attempt, or flees, or resists the attempt and flees, when it is clear that an attempt to arrest him or her is being made, and the suspect cannot be arrested without the use of force, the arrestor may, in order to effect the arrest, use such force as may be reasonably necessary and proportional in the circumstances to overcome the resistance or to prevent the suspect from fleeing:

but, in addition to the requirement that the force must be reasonably necessary and proportional in the circumstances, the arrestor may use deadly force only if -

\footnotetext{
$98 \quad$ Van der Walt 2011 Potchefstroom Electronic Law Journal 142.

99 Report on the OSF-SA roundtable discussion on the human rights and practical implications of the proposed amendment to section 49 of the Criminal Procedure Act: 2010:2. 
(a) the suspect poses a threat of serious violence to the arrestor or any other person; or

(b) the suspect is suspected on reasonable grounds of having committed a crime involving the infliction or threatened infliction of serious bodily harm and there are no other reasonable means of effecting the arrest, whether at that time or later.

The proposed Amendment Bill has been approved by the National Assembly and, at the time of publication of this article, has been submitted to the National Council of Provinces for concurrence. ${ }^{101}$ The revised version of the Bill introduces a clarifying provision, describing 'deadly force' in section 49(1)(c):

(c) 'deadly force' means force that is likely to cause serious bodily harm or death and includes, but is not limited to, shooting at a suspect with a firearm.

Once again the first part of the 2003 redefined section 49(2) (previous 49(1)) is left unchanged and the proposed amendments only focus on the second part of the 2003 redefined section 49(2) - the use of deadly force. The key changes as proposed by the Bill, apart from the added definition of 'deadly force', includes the ejection of the requirement that deadly force can only be used when it is immediately necessary to protect the arrestor, and the allowance of deadly force to be used when the "suspect poses a threat of serious violence to the arrestor or any other person, or the suspect is suspected on reasonable grounds of having committed a crime involving the infliction or threatened infliction of serious bodily harm and there are no other reasonable means of effecting the arrest, whether at that time or later". ${ }^{102} \mathrm{Le}$ Roux-Kemp and Horne ${ }^{103}$ justly laments the replacement of the word "grievous" with "serious", suggesting that if one follows the strict definitions of these words, "serious" denotes a less serious situation that "grievous". This, of course, diminishes the strict criteria for use of deadly force to which the police must comply, while limiting the scope for acquiring liability. ${ }^{104}$

101 SabinetLaw 2012 www.sabinetlaw.co.za/defence-and-security/articles/national-assemblypasses-saps-bill.

102 Report on the OSF-SA roundtable discussion on the human rights and practical implications of the proposed amendment to section 49 of the Criminal Procedure Act: 2010:2.

103 Le Roux-Kemp and Horne 2011 SACJ 281.

104 Le Roux-Kemp and Horne 2011 SACJ 281. 
In addition to the above-mentioned amendments, the "future death" predicament has also been deleted, but it is submitted that the concept thereof is still implied with the removal of the word "immediate" before threat. If there is no need for the existence of an immediate threat, it certainly allows the use of deadly force where the suspect poses a threat at any point in time, including future threats. Once again this will be left open for a wide array of different interpretations and this may lead to serious misuse of deadly force during arrests.

In the preamble to the Criminal Procedure Amendment Bill of 2010, it is stated that the objective of the Bill is to substitute and align the provisions relating to the use of force in effecting arrests with a judgment of the Constitutional Court, namely the Walters-decision (in which the previous section 49(2) was declared unconstitutional). When the 2003 redefined section 49(2) was formulated, the legislature did not have the benefit of making use of the guidelines as set out in the Walters-decision (as discussed above).

In drafting the proposed amendments to section 49, it seems that the legislature did little more than copy and paste from paragraph $h)^{105}$ of the guidelines provided in the Walters-decision, without grasping the background, meaning and interpretation thereof. This unavoidably lead to justified criticism against the proposed amendments by Justice Kriegler (the author of the Walters-judgment and the guidelines used by the legislature), stating that the proposed amendment broadens the circumstances under which lethal force may be allowed and are, in fact, unconstitutional. $^{106}$

Although not specified as part of paragraph $h$ ) of the guidelines, it was first emphasised in the Govender-case that for the use of serious force to be justified, an immediate threat of serious bodily harm to the arrestor or the public had to exist. It was confirmed in the Walters-case "to be at the very least also the prerequisite in a

\footnotetext{
105 "h) Ordinarily, such shooting is not permitted unless the suspect poses a threat of violence to the arrestor or others or is suspected on reasonable grounds of having committed a crime involving the infliction or threatened infliction of serious bodily harm and there are no other reasonable means of carrying out the arrest, whether at that time or later."

106 Report on the OSF-SA roundtable discussion on the human rights and practical implications of the proposed amendment to section 49 of the Criminal Procedure Act: 2010:4
} 
case where the suspect is killed by the arrestor."107 The removal of the word 'immediate' in describing the threat posed by the suspect, does therefore not align the recent, proposed section 49 with a thorough interpretation of the Waltersjudgment, as is the objective of the legislature. This criticism was echoed in submissions made to Parliament on the Bill by The Civil Society Prison Reform Initiative. ${ }^{108}$

The recent section 49(2) further makes provision for the use of deadly force where someone is suspected on 'reasonable grounds' of having committed a crime involving the infliction or threatened infliction of serious bodily harm, without requiring that the suspect poses any threat at all. This would appear to be a movement back to the provisions of the old section 49(2), with the slight difference that it focuses on the commission of any offence involving serious violence, instead of any Schedule 1 listed offence. According to De Vos, ${ }^{109}$ this amendment is unconstitutional and in violation with the right to dignity, life and bodily integrity.

It is submitted that the amendments to section 49(2) is a definite step backwards from the objectives of legislation on the use of force in effecting arrests. This opinion enjoys widespread support. During the public hearings on the Criminal Procedure Amendment Bill, held on 23 August 2011, it was affirmed that passing of the Amendment Bill in its current form would aggravate the problem of the existing high levels of force employed by the police. ${ }^{110}$

\section{COMPARATIVE STUDY}

\subsection{Introduction}

As is the case in South Africa, many foreign police jurisdictions occasionally struggle with the reconciliation of various demands, such as the maintenance of public order

\footnotetext{
107 Ex Parte Minister of Safety and Security ad Others: In re $S v$ Walters and Another [2002] 4 SA 613 (CC) 616.

108 PMG 2011 www.pmg.org.za/print/28019.

109 Report on the OSF-SA roundtable discussion on the human rights and practical implications of the proposed amendment to section 49 of the Criminal Procedure Act: 2010:3-4.

110 PMG 2011 www.pmg.org.za/print/28019.
} 
and basic law enforcement. ${ }^{111}$ The use of force as medium for efficacious law enforcement remains a contentious issue in most countries, but Stone ${ }^{112}$ proposes that there is an international movement towards greater accountability by police officers for the force they employ against civilians.

For the purposes of this article, the guidelines pertaining to the use of deadly force by police officers in the United States of America and the United Kingdom are assessed and compared to those of South Africa.

\subsection{United States of America}

Employment of force, especially deadly force, by members of law enforcement communities is a contentious issue in the United States of America. ${ }^{113}$

Police in America are permitted the legal right to use force ${ }^{114}$ but excessive force ${ }^{115}$ may cause offenders to be subject to criminal prosecution, civil liability, etcetera. ${ }^{116}$ Governing the determination of what constitutes excessive use of force by any police officer in the United States, is the "objective reasonableness" test under the Fourth Amendment ${ }^{117}$ of the Constitution of the United States of America, outlined in Graham v Conner. ${ }^{118}$ The United States Supreme Court held in Graham v Conner that the "objective reasonableness" test is to be applied to all allegations of police use of force, whether during an arrest, an investigation, or other seizures of free citizens, and whether such use of force was deadly or not. ${ }^{119}$

\footnotetext{
Rappert 2002 British Journal of Criminology (42):689. Stone 2007 Theoretical Criminology 245.

Lee and Vaughn 2010 Journal of Criminal Justice 193.

The English common law permitting forceful arrests are still applied in the United States of America and also form the basis of the South African section 49 of the Criminal Procedure Act Du Toit et al. Commentary on the Criminal Procedure Act 5-31.

115 Excessive force can be defined as force that is "unreasonable or unnecessary to accomplish a legal objective" - Lee and Vaughn 2010 Journal of Criminal Justice 193.

116 Lee and Vaughn 2010 Journal of Criminal Justice 193.

117 Constitution of the Unites States of America - The Fourth Amendment dictates the right of people to be secure in their persons against unreasonable searches and seizure, to be protected against violation, and that warrants for arrests may only be issues upon probable cause to do so. 490 U.S. 386, 104 L.Ed.2d 443, 109 S.Ct. 1865 (1989).

Graham v Connor 490 U.S. 386, 104 L.Ed.2d 443, 109 S.Ct. 1865 (1989).
} 
The decision to use deadly force by police officials is guided by the administrative policies and regulations of each police department, or departments in a particular state. ${ }^{120}$ In drafting these policies and regulations, authors must have due regard to the different use-of-deadly-force standards established by case law, legislation, as well as departmental, municipal and public policy. ${ }^{121}$ Drafting authors must also determine whether the use of force, specifically deadly force, will be subject to disciplinary review whenever a firearm is merely discharged, or whether, as in the case of South Africa, review will only take place once the use of force resulted in serious injury or death. ${ }^{122}$

The least restrictive of all the standards on the use of deadly force was delineated in the Supreme Court case Tennessee $v$ Garner. ${ }^{123}$ This case provides for the use of deadly force against fleeing suspects, a provision that is expectedly subject to strict criteria. ${ }^{124} \mathrm{~A}$ police officer may, under this case law, only employ deadly force against a fleeing suspect if: a) the deadly force is necessary to prevent escape, b) the suspect threatened the officer with a weapon or the officer has probable cause to believe the suspect inflicted grievous bodily harm, and c) the officer has warned the suspect of imminent use of deadly force. ${ }^{125}$ This standard is also subject to the reasonableness requirement under the Fourth Amendment of the U.S. Constitution. ${ }^{126}$ Prior to the decision in the Garner case, the United States applied old English common law rules allowing officers to use any means necessary, including deadly force, to arrest felony suspects or prevent them from fleeing. ${ }^{127}$

In support of the Garner case, the U.S. Supreme Court held in 2007 in Scott $v$ Harris $^{128}$ that deadly force may be used during a high-speed vehicle pursuit since the

\footnotetext{
120 Brave and Peters 1992 www.laaw.com/uodfs; Lee and Vaughn 2010 Journal of Criminal Justice 193; Thompson 2011 Report on the workshop: Developing a use-of-force policy for the South African Police Service 7.

121 Brave and Peters 1992 www.laaw.com/uodfs; Lee and Vaughn 2010 Journal of Criminal Justice 193.

122 Mistry et al. 2001 Research report: The use of force by members of the South African Police Service: Case studies from seven policing areas in Gauteng 8.

123471 U.S. 1, 85 L.Ed.2d 1, 105 S.Ct. 1694 (1985).

124 Brave and Peters 1992 www.laaw.com/uodfs.

125 Tennessee $v$ Garner 471 U.S. 1, 85 L.Ed.2d 1, 105 S.Ct. 1694 (1985).

126 Tennessee $v$ Garner 471 U.S. 1, 85 L.Ed.2d 1, 105 S.Ct. 1694 (1985)

127 Tennenbaum 1994 The Journal of Criminal Law \& Criminology 242.

128550 U.S. 372, S.Ct. 1769 (2007).
} 
escaping, speeding vehicle was in fact an instrument of deadly force, endangering innocent lives.

Despite the allowance in Tennessee $v$ Garner, police officers will be held individually accountable where they deviate, even in the slightest, from the set criteria, or recent institutional or legal developments. For example, members of the police force will be held liable where they kill or injure unarmed persons they believed at the time to be armed. $^{129}$

Justification for the employment of deadly force during the execution of an arrest is provided for by section 11.05 of the Model Penal Code. The Code allows for deadly force to be used by police officers during an arrest, only when the following requirements are met: 1 ) the arrest is for a felony, ${ }^{130}$ 2) when the arresting officer believes that force is immediately necessary to execute the arrest or prevent the suspect from fleeing, 3) the intent of the arresting officer has been made clear to the suspect, 4) the officer believes that no substantial risk of harm exists for bystanders, 5) the officer believes that the crime committed by the suspect includes the use or threat of deadly force, and 6) that the arresting officer is of the opinion that there is substantial risk that the suspect will kill or seriously injure someone if arrest is delayed. $^{131}$

The Commission of Accreditation of Law Enforcement Agencies in the United States crafted the so-called "defence of life standard" that dictates that law enforcement officers may employ deadly force only upon the reasonable belief that such action is in defence of life, whether his own or that of another. ${ }^{132}$

A much more restrictive version of the "defence of life standard" employed by some states, including the Dallas Police Department, is the "preservation of life

\footnotetext{
129 Lee and Vaughn 2010 Journal of Criminal Justice 195.

130 A felony is defined as a crime sufficiently serious to be punishable by death or a term in state or federal prison, as distinguished from a misdemeanour which is only punishable by confinement to county or local jail and/or a fine - LAW.COM 2011. Legal dictionary http://dictionary.law.com/Default.aspx?typed=felony\&type=1_Date of use: 5 April 2011

131 LEXISNEXIS Use of force for law enforcement purposes http://www.lexisnexis.com/lawschool/study/outlines/html/crim/crim11.htm date of use: 5 April 2011.

132 Brave and Peters 1992 www.laaw.com/uodfs.
} 
standard". ${ }^{133}$ This standard dictates stricter criteria for the use of deadly force and provides that officers may only use such force when all other alternatives have been exhausted or failed, when there is no risk of harm to bystanders and when, as last resort, serious threat to life exists. ${ }^{134}$

In their research on the topic of standards adopted by police departments, Brave and Peters ${ }^{135}$ state that where police departments adopt certain standards, these standards cannot be less restrictive than posed by the stated case law. Therefore, all criteria expressed in the Garner case must at least be complied with. Police officers must then be trained relentlessly in accordance with the principles and criteria of the chosen standards. Failure to properly train police in the use-of-force policies, especially since governments arm police with firearms and expect them to manage dangerous situations, amounts to an intentional indifference to the rights of those the police interact with. ${ }^{136}$

\subsection{The United Kingdom}

As previously stated, English common law authorised law enforcement officers to employ any means necessary to arrest suspects and to prevent them from escaping. ${ }^{137}$ This rule therefore sanctioned the use of deadly force in circumstances where the suspect posed no risk of harm to the officers or bystanders.

The rules of English common law pertaining to the use of force were repealed by section 3 of the Criminal Law Act of $1967 .{ }^{138}$ This section holds that a person carrying out an arrest may employ such force as is reasonable in the circumstances in the prevention of crime or in effecting or assisting in the lawful arrest of offenders or suspected offenders. ${ }^{139}$

\footnotetext{
Brave and Peters 1992 www.laaw.com/uodfs. Brave and Peters 1992 www.laaw.com/uodfs. Brave and Peters 1992 www.laaw.com/uodfs. Lee and Vaughn 2010 Journal of Criminal Justice 194.

Tennenbaum 1994 Journal of Criminal Law \& Criminology 242.

S 3(2).

S 3(1).
} 
In response to the question as to what constitutes "reasonable" force, section 76 of the Criminal Justice and Immigration Act of 2008 was promulgated. Section 76(3) dictates that a subjective test for evaluation of the reasonableness of the officer's conduct must be used. This section further reads:

\section{Section 76}

"(3)The question whether the degree of force used by $D$ was reasonable in the circumstances is to be decided by reference to the circumstances as $D$ believed them to be, and subsections (4) to (8) also apply in connection with deciding that question."

The Act further holds that in the determination of whether a police officer indeed held a certain belief, due regard must be given to the reasonableness of such belief. If it is determined that he indeed did subjectively embrace such belief, later proof that such belief was mistaken would be irrelevant, unless the mistake was attributable to voluntary intoxication. ${ }^{140}$

Mimicking the proportionality provision in section 49 of the South African Criminal Procedure Act, as well as the recent amendments, section 76(6) of the Criminal Justice and Immigration Act of 2008 stipulates that the degree of force employed by a police officer would not be deemed reasonable in the circumstances the officer believed them to be if the degree of force is disproportionate to the circumstances.

After the terrorist attacks on the United States of America on 11 September 2001, London's Metropolitan Police Service adopted a set of policies pertaining to the use of deadly force, or so-called "shoot-to-kill" tactics, in dealing with suspected terrorists. These policies were referred to as Operation Kratos. ${ }^{141}$

When Jean Charles de Menezes was erroneously shot and killed in London in 2005, a public outcry sounded throughout the United Kingdom as to the freedoms conferred upon police officers by Operation Kratos. ${ }^{142}$ Soon after this incident, Scotland Yard indicated that they altered the rules of this anti-terrorist tactics (though

\footnotetext{
140 S 76(4)-(5).

141 Metropolitan Police Authority Meeting memo http://policeauthority.org/Metropolitan/ downloads/foi/log/kratos-attach.pdf date of use: 5 April 2011 Metropolitan Police Authority 2005:1.

142 Staff and Agencies 2006 www.guardian.co.uk/uk/2006/mar/08/menezes.
} 
the changes were not publicised) and reiterated its use in intelligence led antiterrorism only. ${ }^{143}$

\subsection{Conclusion}

Policing the use of force in effecting arrests in the United States of America differs greatly from that in South Africa and the United Kingdom. Regulation and reviews of instances where violence were used by arresting police officers in America are conducted on state or local level, whereas in South Africa and the United Kingdom, it is performed on national level by way of enacted legislation. ${ }^{144}$

While the proportionality requirement features prominently in the legislative provisions of both South African and the United Kingdom, the United States of America seem to rather place emphasis on reasonability. 'Reasonableness', however, is the feature requisite in all the jurisdictions under discussion. In America, the test for reasonableness is an objective one, contrasted with the subjective test employed in the United Kingdom. The courts in America, for instance, will judge police officers' conduct in light of what the actual circumstances were, as opposed to what the relevant officers believed them to be. South African courts follow the latter approach.

Although the standards for use of force in the United States of America vary between strict and highly restrictive, it remains that American provisions regulating use of force in effecting arrests are more restrictive in nature than that of the United Kingdom. The legislative amendments to section 49 of the South African Criminal Procedure Act causes the regulatory framework of forceful arrests to lean more toward that of lenient United Kingdom, giving arresting officers a greater playing field to use force when arresting suspects.

The reliance on the 'reasonableness' requirement in the United States and United Kingdom causes an immense need for proper and thorough training of the police

\footnotetext{
143 Nicol Main on Sunday 2.

144 Thompson 2011 Report on the workshop: Developing a use-of-force policy for the South African Police Service 7.
} 
officers required to interpret the regulatory provisions within a very brief decisionmaking window. It is therefore incumbent upon the governments and police authorities to provide training to those expected to enforce the law in sometimes volatile situations.

\section{CONCLUSIONS AND RECOMMENDATIONS}

It is an unobjectionable fact that the use of force, even deadly force, in effecting arrests is unavoidable in certain situations. The circumstances and degree to which it may be employed has, however, been under debate for centuries. South Africa is again on the verge of legislative changes with regards to the powers conferred to police in using force in carrying out arrests.

The acceptance and institution of changes as proposed by the Criminal Law Amendment Bill of 2010, represents a definitive widening of police powers to use force. This is great cause for concern. Relaxed criteria for the use of force, including deadly force, could potentially lead to police officers using violence unnecessarily and freely in carrying out arrests.

Although clumsily worded, the 2003 redefined section 49(2) is aligned with the provisions of the Constitution of the Republic of South Africa to a much greater extent than the recent amendments, and it extends the powers of arrestors beyond mere common law private defence.

Of course, there is scope for improvement on the 2003 redefined section 49. Its vague formulation can be cured by including definitions for 'deadly force', as can be found in the amendments approved by the National Assembly, as well as for the term 'substantial risk of future death'.

Ideally, the concept of use of violence in arresting youth offenders should also be addressed in legislation, ${ }^{145}$ as well as the safety and security of bystanders where force is used in effecting arrests, as is the case in the United States of America with,

145 Report on the OSF-SA roundtable discussion on the human rights and practical implications of the proposed amendment to section 49 of the Criminal Procedure Act: 2010:5. 
for example, the Model Penal Code provisions and the 'preservation of life' standard. ${ }^{146}$

One should also not lose sight of the fact that, regardless of provisions of the 2003 redefined section 49, the number of killings by police officers has increased tremendously over the last few years, highlighting the disability of legislation alone to control use of force by police. ${ }^{147}$ Mistry et al. ${ }^{148}$ reminds us that legislative alterations impact the number of suspects injured or killed by police officers on the short term only, and that meticulously designed strategies must be developed to supplement legislative provisions regulating use of force in effecting arrests. It is therefore submitted that in addition to the legislative rules, the South African Police Service formulate policies to further delineate and clarify appropriate conduct in situations traditionally requiring the employment of violence in arresting suspects.

The importance of training along with the development and adoption of internal policies cannot be overstated. ${ }^{149}$ This will have the effect of increasing the standards of objective belief, which, in turn, will lead to certainty amongst police officials in when and how to use force effectively and justifiably. The many challenges faced by arresting officers everyday can only be overcome through proper training. ${ }^{150}$

Burger $^{151}$ supports the need for training and suggests the following to minimise unreasonable application of force in effecting arrests:

i) Capacitating the SAPS Training Division to enable adequate training

ii) Ensuring that proper command and control systems are in place at police stations

iii) Strengthening the police's internal inspectorate to conduct regular inspections

\footnotetext{
146 American Penal Code: S 11.05(4). See also Bruce "Shoot to kill: The use of deadly force by police" 9.

147 Bruce 2011 SA Crime Quarterly 5-6.

148 Mistry et al. 2001 Research report: The use of force by members of the South African Police Service: Case studies from seven policing areas in Gauteng 9.

149 Bruce 2011 SA Crime Quarterly 6. Also see Le Roux-Kemp and Horne 2011 SACJ 282.

150 Mistry et al. 2001 Research report: The use of force by members of the South African Police Service: Case studies from seven policing areas in Gauteng 7.

151 Open Society Foundation for South Africa Report on the OSF-SA roundtable discussion on the human rights and practical implications of the proposed amendment to section 49 of the Criminal Procedure Act 2010:8-9.
} 
iv) Enabling the ICD to effectively perform its oversight functions to ensure that every incident of the use of deadly force and all forms of serious misconduct are investigated and where appropriate, criminally prosecuted.

It will also be of great benefit to adopt 'standards of use of force' or internal police policies, as is the practice in the United States of America, whether nationally or provincially, in terms of which police officers must be trained and continuously informed and assisted regarding the decisions involved in the use of force while carrying out their duties. Until such pragmatic options are adopted and implemented with the full dedication and focus of police management, legislation in all forms and variations is likely to have little success.

Finally, on the issue of police safety, it has been submitted ${ }^{152}$ that widened powers to use force during arrests will not serve to increase the safety of police officers in the line of duty. ${ }^{153}$

152 As part of submissions made to Parliament on the Criminal Procedure Amendment Bill on 23 August 2011.

153 Bruce "Submission to The Portfolio Committee on Justice and Constitutional Development" s.p. 


\section{Bibliography}

Bekker et al. 2009 Criminal Procedure

Bekker PM, Geldenhuys T, Joubert JJ, Swanepoel JP, Terblanche SS and Van der Merwe SE Criminal Procedure Handbook $9^{\text {th }}$ ed (Juta \& Co Claremont 2009)

Brave and Peters 1992 What's your use-of-deadly-force standard?

Brave MA and Peters JG 1992 LAAW International, Inc. What's your use-ofdeadly-force standard? www.laaw.com/uodfs

[Date of use 15 Feb 2011].

Bruce 2011 SA Crime Quarterly

Bruce D "Beyond section 49: Control of the use of lethal force" 2011 South African Crime Quarterly 36:3-12.

Bruce 2010 Conference on Policing in South Africa

Bruce D "Shoot to kill: The use of deadly force by police" in the Report on the Conference on Policing in South Africa: 2010 and beyond 30 September to 1 October 2010 Muldersdrift 8-9.

Bruce 2011 Re: Criminal Procedure Amendment Bill, 39 of 2010

Bruce D "Submission to The Portfolio Committee on Justice and Constitutional Development" Re: Criminal Procedure Amendment Bill, 39 of 2010. 22 July 2011 s.p.

Burchell 2011 SACJ

Burchell J South African Criminal Law and Procedure Vol 1: General principles of criminal law $4^{\text {th }}$ Edition. (Juta Claremont 2011)

Du Toit et al. 2010 Commentary on the Criminal Procedure Act

Du Toit E, De Jager FJ, Paizes A, Skeen A St Q, Van der Merwe S Commentary on the South African Criminal Procedure Act (Juta Cape Town 1987-2010) 
Geldenhuys 2010 Conference on Policing in South Africa

Geldenhuys T "Shoot to kill: The use of deadly force by police" in the Report on the Conference on Policing in South Africa: 2010 and beyond 30 September to 1 October 2010 Muldersdrift 9-10.

Harrendorf et al. (Eds) 2010 International statistics on crime and justice

Harrendorf S, Heiskanen $M$ and Malby $S$ (Eds) International statistics on crime and justice (HEUNI Publication Series No 64 United Nations Office on Drugs and Crime (UNODC) Helsinki 2010)

Institute for Security Studies 2008 International Comparative Statistics Institute for Security Studies 2008 International Comparative Statistics www.issafrica.org/crimehub/pgcontent.php?UID=1000048

[Date of use: 6 April 2011].

\section{LAW.COM}

2011. Legal dictionary http://dictionary.law.com/Default.aspx?typed=felony \&type=1 [Date of use: 5 April 2011]

Lee and Vaughn 2010 Journal of Criminal Justice

Lee $\mathrm{H}$ and Vaughn MS "Organizational factors that contribute to police deadly force liability" 2010 Journal of Criminal Justice 38:193-206.

Le Roux-Kemp and Horne 2011 SACJ

Le Roux-Kemp A and Horne CS "An analysis of the wording, interpretation and development of the provisions dealing with the use of lethal force in effecting an arrest in South African criminal procedure" 2011 South African Journal of Criminal Justice 24(3):266-282.

\section{LEXISNEXIS}

Use of force for law enforcement purposes

http://www.lexisnexis.com/lawschool/study/outlines/html/crim/crim11.htm [Date of use: 5 April 2011]

Metropolitan Police Authority 
Meeting memo

http://policeauthority.org/Metropolitan/downloads/foi/log/kratos-attach.pdf [Date of use: 5 April 2011]

Mistry et al. 2001 Research report: The use of force by members of the South African Police Service: Case studies from seven policing areas in Gauteng

Mistry D, Minnaar A, Redpath $\mathrm{J}$ and Dhlamini $\mathrm{J}$ The use of force by members of the South African Police Service: Case studies from seven policing areas in Gauteng September 2001 (Institute for Human Rights \& Criminal Justice Studies, TechnikonSA).

Neethling and Potgieter 2004 TSAR

Neethling $\mathrm{J}$ and Potgieter JM "Section 49 of the Criminal Procedure Act 51 of 1977, private defence and putative private defence: regspraak" 2004 Tydskrif vir die Suid-Afrikaanse Reg 3:602-608.

Nicol 2005 Mail on Sunday

Nicol M "Met changes shoot-to-kill rules...but keeps them secret" 2005 Mail on Sunday October 9:2.

Open Society Foundation for South Africa 2010 Report on the OSF-SA roundtable discussion on the human rights and practical implications of the proposed amendments to section 49 of the Criminal Procedure Act

Open Society Foundation for South Africa Report on the OSF-SA roundtable discussion on the human rights and practical implications of the proposed amendments to section 49 of the Criminal Procedure Act 28 April 2010 (Johannesburg, South Africa)

Rappert 2002 British Journal of Criminology

Rappert B "Constructions of legitimate force" 2002 British Journal of Criminology 42:689-708. 
Keebine-Sibanda and Sibanda 2003 Crime Research in South Africa

Keebine-Sibanda MJ and Sibanda OS "Use of deadly force by the South African Police Services re-visited" 2003 Crime Research in South Africa 5(1)s.p.

Smith 2009 Guardian.co.uk

Smith D 2009 South Africa considers 'shoot to kill' policing ahead of World Cup www.guardian.co.uk/world/2009/sep/16/south-africa-police-world-cup [Date of use 10 March 2011].

Snyman 2008 Criminal Law

Snyman CR Criminal law $5^{\text {th }}$ ed (LexisNexis Durban 2008).

South African Police Service Annual Report

South African Police Service Annual Report 2008/2009 www.saps.gov.za [Date of use 6 April 2011].

South African Police Service Annual Report 2009/2010 www.saps.gov.za [Date of use 6 April 2011].

Staff and Agencies 2006 Guardian.co.uk

Staff and Agencies 2006 Police defend Menezes shooting tactics 8 March www.guardian.co.uk/uk/2006/mar/08/menezes

[Date of use: 15 Feb 2011].

Stone 2007 Theoretical Criminology

Stone C "Tracing police accountability in theory and practice: From Philadelphia to Abuja and Sao Paulo" 2007 Theoretical Criminology 11(2):245259.

Tennenbaum 1994 The Journal of Criminal Law \& Criminology

Tennenbaum AN "The influence of the Garner decision on police use of deadly force" 1994 The Journal of Criminal Law \& Criminology 85(1):241-260. 
Thompson 2011 Report on the workshop: Developing a use-of-force policy for the South African Police Service

Thompson J Policing in a violent democratic society: Lessons in the use of force from the United States. In: Report on the workshop: Developing a useof-force policy for the South African Police Service 21-22 July 2011 (Emoyeni Conference Centre, Johannesburg, South Africa).

Van der Walt 2007 TSAR

Van der Walt T "'n Grondwetlike oorsig oor die gebruik van geweld tydens arrestasie deur die Suid-Afrikaanse Polisiediens" 2007 Tydskrif vir die SuidAfrikaanse Reg (1):96-111.

Van der Walt 2011 PER/PELJ

Van der Walt $\mathrm{T}$ "The use of force in effecting arrest in South Africa and the 2010 Bill: A step in the right direction?" 2011 Potchefstroom Electronic Journal (14)1:138-162.

\section{Legislation}

Constitution of the Republic of South Africa of 1996

Criminal Procedure Act 51 of 1977 (South Africa)

South African Police Service Act 68 of 1995

\section{Register of cases}

April v Minister of Safety and Security [2009] 2 SACR 1 (SE)

Ex parte: Minister of Safety and Security and Others: In Re $S v$ Walters and Another [2002] 4 SA 613 (CC)

Govender v Minister of Safety and Security [2001] 4 SA 273 (SCA)

Matlou v Makhubedu [1978] 1 SA 946 (A) 